4th International Scientific Conference SEC-IASR 2019, Galati, Romania, 7th - 8th June, 2019

\title{
Canonical Authors and the Identity Values in the High School Curriculum
}

\author{
Nicoleta CRÎNGANU \\ https://doi.org/10.18662/lumproc/sec-iast2019/15
}

How to cite: Crînganu, N. (2020). Canonical Authors and the Identity Values in the High School Curriculum. In S. Marin \& P. Moisescu (vol. eds.), Lumen Proceedings: Vol. 12. 4th International Scientific Conference SEC-IASR 2019 (pp. 125-139). Iasi, Romania: LUMEN Publishing House.

https://doi.org/10.18662/lumproc/sec-iasr2019/15 



\title{
Canonical Authors and the Identity Values in the High School Curriculum
}

\author{
Nicoleta CRÎNGANU ${ }^{1}$
}

\begin{abstract}
The school literature is the most important object in transmittind, configurating and consolidating the value system of a people. The school curriculum is not anymore a simple list of authors and works, its' structure is more complex keeping in mind the triple status of the Romanian Language and Literature in the Romanian school system - as official tongue of the state, as a school language and a school study subject. However, the list of canonical authors is significant for the curriculum's authors vision about the value system that the community intends to develop at the future generations. In this respect, two visions are confronted about the Romanian Language and Literature curriculum: the traditional one, that insists on some literary values that cannot be repealed, and the other one, a (post)modern vision that emphasises the pleasure of the reading/ of the text and on the student's needs. Regardless of the position of the curriculum author, it is fundamental that the studied literary works propose not only aesthetic values, but also ethic and identity values. For this reason, the options cannot be random. Something that has been learnt as a buman model, studied during literature classes stays as a mental program for the lifetime.

This paper is aims to identify a series of ethic and identity values as the can be found in the texts studied by high school students through the list of canonical authors, showind as well how the disappearence or the insertion of some writers and literary works have an impact on collective mind.
\end{abstract}

Keywords: school literature; curriculum; collective mind. 
Nicoleta CRÎNGANU | Lumen Proceedings 12 | SEC-IASR 2019

\section{Introduction}

If, during the communist period, the concern for identity construction was related to the regime's propaganda, which promoted communist nationalism, in the post-revolutionary years, the identity paradigm changed, both in terms of social communication and in the educational context. The curriculum authors discarded, not always appropriately, to some writers and to their works, new authors, not previously studied being introduced, in the school curriculum.

After joining the European Union, the problem of national identity began to become more and more acute, as the debate about it became more acute. The fundamental problem of the authors of the school programs was that of preserving the national specificity of the Romanian written culture without slipping into the communist nationalism in which they had been educated. At the same time, the identity dimension, with an important educational function, could not exceed the aesthetic one, because, the curriculum was supposed to generate good book readers, besides of citizens aware of their own culture and values. Suffocated by the communist propaganda, the Romanians valued themselves in two fundamental ways ethnocentric and ethno-peripheral [8]. These paradoxical approaches are connected by Alex Goldiş [7] to the fragility of the Romanian nation. In this context, the researcher speaks about an allegory of identity as he insists, quoting Gregory Jusdanis, that 'before being gained as a political value, the national unity discursively constructed' [7]. Furthermore, Goldiş quotesErnest Geller who assignes the proliferation of the discours on the nation by the absence of its political or institutional realisation: 'The nationalism does not represent the self-awareness of nations, as has been said, but the invention of them where they do not exist'[7]. That is why the literary history and as well the school curricula that is made according to the use of this history 'becomes here a privileged speaker of the identity values, exceeding their scientific responsibilities of collecting and evaluating of the works in favor of this ethnic organicity cultural construction process [7].

Replacing the propagandist communist mythology, however, proved not to be a very easy thing to do, because the attempts to demystify, such as those of Eugen Negrici [16] or Lucian Boia [2], [3], some of them even devastating, such as those regarding MihaiEminescu, produced outrage in the academic environment, sometimes for good reason. The debate on the canon and, implicitly, on the national and identity specificity has lasted for almost twenty years and threatens to extend in the context in which "we must know what meaning we give to the national identity, which is not, as we have seen above, only a sociological or theoretical construction, but a 
concept that expresses behaviors, attitudes and mentalities encountered in large groups of Romanians'[23].

Although the concern for national identity, nation, national specificity is associated with the young states, with less stable borders (category in which Romania is included, as being built as a state in 1918), the problem of its identity and its construction is all the more significant as the communist regime acted, through different forms of propaganda, to the configuration of a national mythology, related to a pro-Soviet identity construct.Its strength, its survival in the collective mind, generated both the attempts to demystify, as well as a pious contemplation of values, on the other hand, but also the return to the interwar values, considered a kind of "golden age", as Carmen Mărcuş observes: 'On the cultural level, after 1989, a recovery of the interwar period is being pursued, as it is considered the last 'normal' period in the history of Romania' [15]. It is precisely this that shows that 'any demythification is concomitant with a remythification'[11], because the golden age reminds of the communist "golden age", a phrase that somehow brought together the myth of the lost paradise and the eschatological utopia.

\section{Problem Statement}

Identity construction is a concern of many sciences - from history, to philosophy, from sociology to psychology and last but not the least, to the national literature and its didactics. In this context, it is worth mentioning the canonical literature debate, with both didactic and identity stakes. The historians relate it to the national state, the sociologists and the psychologists follow the collective mind, the political scientists andthe political marketing specialists examines the myths and the symbols of the collective mind from the more pragmatic perspective of the use in an electoral context.About the characteristics of the Romanian people many scientists wrote in the interwar period and, later, in the post-December period. Among the authors we can mention Constantin Rădulescu-Motru [19], Mircea Vulcănescu [27], MihaiRalea [18], Daniel David [6], Dumitru Drăghicescu, Garabet Ibrăileanu [10], Lucian Boia, Septimiu Chelcea, Eugen Simion, Eugen Negrici, Alex Goldiş etc. If for the psychologists, sociologists and historians, the most significant problem is connected to the specificity of national mythology, the narratives of legitimation, the dynamics of myths and the way in which the communism has changed the collective mind, for literary historians, the identification of the national specificity and the characteristics of the collective mind is related to the literature and its connection to aesthetics. 
For the didactic researcher, the problem of the literature curriculum, of the texts with identity content involves forms of identity construction, conscious or not. In fact, Alex Goldiş [9], as teaches us, there are two ways to approach the problem of identity: a static one, according to which the identity is a natural given, immutable, and a second one, dynamic, for which the construction of the identity sense changes depending on the epochs and on the education. In this context, besides the issue of national identity, the school syllabus must also take into account the literary canon, which leads to a second significant battle of the Romanian literary theorists.

\section{Research Questions/Aims of the research}

The publication of the new school curricula for the secondary school has reopened the debate on the relation between the school curriculum, canon and identity construction, the disappointments of some contestants being related to the absence of compulsory authors in the secondary school. The issues that this article endeavours, however, are related to the identity content of the high school curriculum, the more so as it should be renewed, as well as the secondary school one was. In this context, the re-evaluation of the canonical authors of the high school curriculum, writers who also appear in the Baccalaureate curriculum, of their works that are introduced in school textbooks, the disappearance of some writers, after 1989, the appearance of others and the impact of their works in the collective mind is the goal of the present research. It aims to open the discussion on the post-communist identity dynamics, as well as the school's function in its construction. The working hypothesis is that the myths promoted by communist regime through school syllabus have not disappeared, even if some of the texts are no longer found in programs and textbooks, but the collective mind has kept them, even formally modified, in the media.

\section{Research Methods}

The research methodology involved both the study of the school curricula (communist and post-revolutionary), of the authors considered canonical in the two periods, as well as the application of some concepts and definitions of sociology to the texts and authors of literature included in the school syllabus. Subsequently, the inventory of some identity components found in the media completes the investigation of the identity construct, in order to identify the myths and identity features that reach the media as a reflection of the school texts and study. 
Nicoleta CRÎNGANU | Lumen Proceedings 12 | SEC-IASR 2019

\section{Findings}

During the communist period, the school programs for Romanian language and literature, at the high school level, were almost exclusively lists of authors and works, arrangedaccording to the chronological criterion. Thus, the study of literature began with the period of old literature, the first known writing in Romanian language (Neacşu's letter from Câmpulung), followed by the first printings, Moldavian chroniclers, Dimitrie Cantemir, Ion Budai Deleanu. It followed with "paşoptist" literary currentwith Costache Negruzzi, Grigore Alexandrescu, Vasile Alecsandri, the junimism, with Mihai Eminescu, Ion Luca Caragiale, Ioan Slavici, Ion Creangă, and the extensions of the era of the great classics at the end of the 19th century and the beginning of the 20th century with writers as Alexandru Macedonski, Octavian Goga, George Coşbuc or Barbu Ştefănescu Delavrancea.There are no major changes in the list of the writers and works studied interwares: they were also studied during the (late) communist period George Bacovia, Dimitrie Anghel, Ion Minulescu, Lucian Blaga, Tudor Arghezi, Ion Barbu, Mihail Sadoveanu, Camil Petrescu, George Călinescu, Liviu Rebreanu. Without being subject to any political correctness, Hortensia PapadatBengescu was included in the school curriculum, but Vasile Voiculescu, Mircea Eliade or Ion Pillat were missing. The period of contemporary literature has undergone the most important changes: texts of Marin Preda, Nichita Stanescu or Marin Sorescu were being studied, as well as valuable writers or those who made a pact with the regime: Mihai Beniuc, Eugen Jebeleanu, Miron Radu Paraschivescu, Geo Dumitrescu, Augusttefan Augustin Doinaş, Nicolae Labiş, Zaharia Stancu, Geo Bogza, Eugen Barbu, Titus Popovici, Fănuş Neagu, Alexandru Ivasiuc, Horia Lovinescu, Aurel Baranga, Paul Everac.In the present days, the canonical authors are far fewer: Mihai Eminescu, Ion Luca Caragiale, Ioan Slavici, Ion Creangă, George Bacovia, Lucian Blaga, TudorArghezi, Ion Barbu, Mihail Sadoveanu, Camil Petrescu, George Călinescu, Liviu Rebreanu, Marin Preda, Nichita Stănescu and Marin Sorescu.

The texts studied by the high school students during the communist regimeoutlined a narrative of legitimation in which the golden age utopia, the myth of the civilizing and liberating national hero were combined with another central myth - the struggle: the struggle for the preservation of the national being, the class struggle, the fight for peace (with all the paradox that the last phrase implies).Studying the old literature, the students assumed the Latin origin, promoted by chroniclers such as Grigore Ureche (with his famous saying "from Râm wecome - de la Râm ne tragem"), Miron Costin (through his controversial work "About the Moldovan People ... - De 
neamul moldovenilor"), by reading some texts of Dimitrie Cantemir, such as "Description of Moldova", which was studied in school, but also by references to "The Chronicle of the Durability of the Romans-MoldaviansWallachians- Hronicul vechimii a romano-moldo-vlahilor". In this context, the discussions on the Transylvanian School, together with the historicallinguistic observations regarding the origin of the Romanian people, also cultivated the nationalist-identity mythology. The purpose of such an approach was to set up an identity narrative that associated Romanian ethnocentrism with the vocation of the struggle for national unity. In this context, the Latin origin was associated with the troubled history, in which the rescuer hero defends the Christianity, along with the defense of the national borders. The most important hero of this type, celebrated by the communist regime was Stefan cel Mare (Stephen the Great). He is introduced in the Communist high school curriculum by the work of Grigore Ureche ("Letopisețul Țării Moldovei"), where the portrait that the author made to the ruler stands under the sign of exceptionalism: exceptional warrior ("master in the things of wars - la lucruri de războaie meşter ", "rarely didn’t win a war - raru războiu de nu biruia "), who fought together with his soldiers ("where he was needed he threw himself - unde era nevoie însuşi se vârâia"), tenacious ("he has risen above the victors - se rădica deasupra biruitorilor"). The portrait made by the chronicler is supplemented, in the school syllabus, with the image of Stefan cel Mare as superhuman energy, in "Sunset - Apus de soare" by Barbu Stefannescu Delavrancea, where the hero's gaze (also called the old eagle) burns the conspiracy boyars, killing the cup bearer Ulea even before being hit, only because of the force of Stefan's gaze; he transforms the cry of pain, when the wound is burned, into a battle cry, he imposes his will even after the physical death. He enthrones Bogdan as a leader of Moldova, against the will of the boyars. However, to make complete the virtues of the rescuer hero, the curriculum introduces the third work dedicated to Stefan cel Mare, the novel "Brother Jderi - Frații Jderi" by Mihail Sadoveanu, where Stefan appears as the father of the nation, under whose reign Moldova thrives, and the people, grateful, gathers around the beloved ruler. The broad hints to the slogans of the "golden age" and to the "beloved ruler" are self-imposed.

Although in the post-communist curricula[34], [35], [36], the insistence on the beloved leader, the savior hero, is diminished, some texts regarding Ştefan cel Mare's personality remain in thesyllabus and the textbooks. In addition to the works of the chroniclers, Delavrancea's drama or Sadoveanu's novel, the students learned a poem by Vasile Alecsandri, "Red Grove - Dumbrava roşie", with the same warrior-rescuer connotations. 
An important change of vision of the school curricula appears in 1998, when they change radically, the lists of authors and texts disappear, the Romanian teacher winning the freedom to select those support - contents that he considers necessary. In this way, the "Brother Jderi"novel, the "Sunset" drama and the "Red Grove" poem gradually disappear. Vasile Alecsandri remains in textbooks through his descriptive poems and Barbu Delavrancea disappears. Mihail Sadoveanu is an interesting case in this context, because, besides the novel "The Hatchet - Baltagul" that never disappears from the textbooks, two other writings of his are proposed for student study: "Cancer sign or Duca -vodă's time- Zodia Cancerului sau vreme Ducăi-vodă", respectively, "The Golden Bough - Creanga de aur".

The changeable nature of the sadovenian work allows the change of the identity vision. Thus, together with thethe chroniclers' claimed latinity the veneration of Dacians is introduced, through the image of Kesarion Breb, wrapped up in a new magical light. Without proposing to the students any debate on the importance of the Dacian element in the formation of the Romanian people, the last curriculum of the second millennium, however, suggests a new vision, overcoming the Dacian virtues. Only the 2009 school curriculum insists on the Daco-Latin synthesis, inviting the students to an entire case study related to the Romanians' Latin and Dacian origin. With the other novel, "Cancer sign or Duca -vodă's time -Zodia Cancerului sau vreme Ducăi-vodă ", it is proposed, for the first time in the Romanian language and literaturecurriculum, the motif of the stranger (Marenne's abbot) and of the locals' relations with him. The terms in which this relationship is discussed are those derived from the self-image of the Romanians - hospitality and humanity, because the abbot is well received and welcomed by Alecu Ruset, even if the host himself is in great danger.The adventures illustrate, in essence, the characteristics of the Romanians postulated by Septimiu Chelcea, Constantin Schifirneț, Eugen Simion, if we are to refer to only a few observers. What is is essential it that the identity narrative becomes more complex through introducing in the identity equation the study of the Dacian heritage, on the one hand, and relations with the Other, on the other hand.

The identity myths develop their meanings obtained through education, in the collective mind, illustrated in the media. The myth of the hero and the rescuing leader is reconfigured into media characters such as Ion Iliescu, Traian Basescu [12], [22], [29] and, more recently, Laura Codruța Kovesi. The first, often presented by the press - ironically or not - as the "father of the nation" [14] accepted as such by the Romanian exegesis (see Adriana Marinescu). Traian Basescu, framed in the typology of a local outlaw as Robin Hood by Adriana Marinescu, structures his character on the 
coordinates of the savior hero, as well, illustrated by the media as such. The case of Laura Codruța Kovesi is interesting in this context.Built on the motif of the anti-corruption fight, the character was compared to Ioana d'Arc [30], Nefertiti [17], preferred foreign heroines, instead of the Romanians, either because the Romanian mind is not prepared for a hero-woman, or because an Ecaterina Teodoroiu did not have the size of the other two. However, the myth of the savior heroine is built in opposition to the heroines -grey eminencesof different political regimes, from Elena Lupescu, to Elena Ceaussescu or Elena Udrea. The Kovesi heroine has, in the mind of the people, Ana's wife of Manolepower of sacrifice, but the construction pattern behind the character is the one of Sadoveanu's Vitoria Lipan: she tenaciously pursues her purpose, builds narratives around antagonists, uses the force of the event to reveal the crimes.

The myth of the savior hero recalls another recurring myth in the Romanian collective mind, that of the endangered homeland. Itpenetrates the conscience of the students starting with the study of the chroniclers, followed by the representatives of the Transylvanian school, to the militant writersof the paşoptist literary current. Among them, Grigore Alexandrescu exults in his work "The Shadow of Mircea. At Cozia - Umbra lui Mircea. La Cozia", the image of a heroic Mircea the Elder, defender of the endangered homeland. The image is tinted in "Letter III" by Mihai Eminescu, introduced in all the school programs, in the fragment of the meeting between the ruler and the Sultan Baiazid suggesting precisely the relationship between the saving hero and the endangered homeland: „Eu îmi apăr sărăcia şi nevoile şi neamul/ Şi de aceea tot ce mişcă-n țara asta, râul, ramul/Mi-e prieten numai mie, iarăţie duşman este" (I defend my poverty and needs and nation / and therefore everything moving in this country, the river, the branch / Is only my friend, but for you is an enemy), adding the warrior component, in the sequence of the battle: „Mircea însuşi mână-n luptă vijelia-ngrozitoare"(Mircea himself rules in fight the outrageous storm),supplementing it with the fondation vocation, with the love in the center of the world, in the letter sent to his "dear" by the son of the Lord; in the same way, Costache Negruzzi proposes a tyrannicalruler, whose behavior touches pathological elements, but motivates his actions precisely through theendangered homeland threatening, but this danger is not from outside, from the Ottoman invasions, but from inside, from the betraying of the boyars.

The class struggle was the most powerful myth of the communism. It threatens the city, but allows the savior hero to show himself. The communist school curriculm [33] find the class struggle in the rebellion against Alexandru Lăpuşneanu, in Costache Negruzzi’s short story, in 
Eminescu's poem "Împărat şi proletar" (Emperor and proletarian), in the novels of Liviu Rebreanu, "Ion" and "Răscoala", the poems of Octavian Goga ("Plugarii", "Clăcaşii" were studied), in the works of George Coşbuc ("Noi vrem pământ - We want land"), in the novels of Marin Preda ("Moromeții"). Most of the explicit propagandistic texts disappeared from the curriculum. After 1989, the pupils do not study "Împărat şi proletar" anymore, nor "Liviu Rebreanu's "Răscoala", and Octavian Goga is present in the textbooks with poemslike "The Prayer", George Coşbuc, with "Nunta Zamfirei" (Zamfira's wedding)[34, 35, 36]. The texts that have not been abandoned are interpreted from other perspectives, based on inter-war literary criticism, such as "Ion", which is discussed of in some terms established by the interwar literary criticism: the character is a "brute", as George Călinescu saysor he acts with "procedural cunning", as E. Lovinescu writes. Moromete is no longer the oppressed peasant, whose son embraces the ideas of communism, but the misfit who does not want to understand the transformation of the Romanian village.

However, the class struggle has not disappeared from the collective mind, and it can still be found in various formulas, from the explicit one, the suspicion related to the acquisition of the wealth by the businessmen - for example, an article from the Iasi press lists the "colossal assets" made "on the back of the people "[20], another [28], in which the advice offered by a company is considered theft or another that analyzes the disappearance of the assets of the communist unions [31].

Deeply rooted in the collective mind, the class struggle took other, more subtle forms - the demonisation of the political class [1], understood as the new bourgeoisie, the fight against corruption [32], associated with the enriched political class, the resistance to the attempts of the cultural, spiritual, economic"colonization" of Romania [4], [5], [13], [21], [24], [26]. Ultimately, the communist class struggle, metamorphosed into various wars of the Romanian people, illustrates yet another subtle and unexpected component of the collective mind: the fear of the Other. Normally, Romanians think of them as hospitable and adaptable, they readily accept otherness, but nevertheless, they cannot repress their fear in the face of the stranger's metamorphosis: "In Romanian mind, omnipresent is the metaphor of the honoured guest stranger who suddenly changes into the owner of the space in which he was received", Ovidiu Ivancuwrites [11]. The stranger is thus under the sign of a paradox: he is expected to be a savior (Americans), as an investor, but at the same time, he is feared as an invader and oppressor, according to the communist vision that still resists in the postdecembrist collective mind. 
The Communists had created a true religion of the "new man", of equality, equity, of sharing of goods according to the needs. The official propaganda drove away from the center of the collective imaginary the orthodox spirituality. Religious allusions were forbidden, writers and texts of this kind could not appear in textbooks and in thecurriculum or in the lessons of Romanian language and literature. The prohibition of involvement in the religious life was associated with the complete ignorance of this dimension of literature. However, secretly, reading religious texts was a form of cultural resistance, the immediate consequence of which was the introduction of authors and works with religious content into the school curricula. One of the first writers introduced into the high school syllabus [34] was Vasile Voiculescu.The first poetry that the students studied was "În Grădina Ghetsemani" (In the Garden of Gethsemane), the discovery of "Ultimele sonete în traducere imaginară de Vasile Voiculescu" (Last sonnets imaginary translated by Vasile Voiculescu) was a few years later for the Romanian schoolbooks and students. At the same time, the students could discover Eminescu's religious works, such as "Rugăciune" (The Prayer) or "Răsai asupra mea" (Rise over Me), then the texts of Ion Pillat or "Jurnalul fericirii" (The Diary of Happiness) by Nicolae Steinhardt. In the textbooks, some texts of Nechifor Crainic or other writers from „Gândirea” magazine have appeared sporadically, the interpretation of some Blagian or Arghezian texts has also begun to take into account the spiritual-religious component. If, during the communist period, in teaching Tudor Arghezi the teachers insisted on the "Testament" or the poems from the "Cântare omului"cycle, in the post-December period the Psalms or the cycle of "Flori of mucigai" are introduced.

Beginning with the religious commitment the search for the spiritual dimension, forbidden during the communist regime, diversifies and shades. One of the first authors introduced into the Romanian language and literature programs is Mircea Eliade, read with the greed of the thirsty man who reaches the desert oasis. His fantastic short stories have even delighted generations of students, from "Nopți la Serampore" (Nights in Serampore) "La țigănci"(At the Gypsies) or "Pe strada Mântuleasa" (On Mântuleasa Street), then the writer will be used with other works as "Maitreyi" or "Romanul adolescentului miop" (The novel of the myopic teenager). In the same context, the first postdecembrist curriculum recovered Constantin Noica ("Introducere la dor") and Emil Cioran[34].Moreover: the latest high school curricula (2009) suggest as case studies "The Formation of historical consciousness", "Latinity and Dacism" (where the recrudescence of identity myths can be easily recognized), and, more important, a case study entitled "The religious dimension of the life", thus promoting religious commitment 
as a value. Of course, other arguments can be added here, such as introducing religious subjects in schools, celebrating religious holidaysetc. The curricula and classes of Romanian language and literature supplement this return to a fundamental identity value: "the national identity is defined by the specific characteristics, we say unique, of a nation, such as language, culture, religion, but also by the observance of customs, traditions, specific usage of the national community "Constantin Schifirneț writes [23], thus placing the religion alongside language and culture.

Searched in the media, the religious dimension proves its strength. The church even becomes an institution that is strongly promoted, thus promoting Romanian symbols and customs. On holidays such as Christmas, Easter, God Baptism etc, the press institutionsare invited to broadcast the events piously. The Christmas and Easter mass are broadcasted live on the television, and throwing the cross in the water, on the occasion of the God's Baptism Day is a ritual show with a mobilizing role. Other examples can be added, essential being the identity tendency, the return of religious commitment in the school programs, this time, the pressure is not anyore exerted from the curriculum towards the collective mind, but vice versa. The release of the religious spirit in the community has led to the reflection of this tendency in school curricula. However, the relationship with God, writes Eugen Simion in an essay published in the "Culture"journal, remains "relaxed": "Religion is for them, above all, a moral that they respect, and those who do not respect are despised, they are considered "rejected by God."[25]

In the mentioned text, Eugen Simion analyzes other components of the Romanian collective mind: the earth as a sacred value, the language as the most powerful element of reference, the idea of unity, the active tolerance (associated with religious commitment) the moral of survival, illustrated by the proverb "The sword does not cut the bent head", the adaptability observed by other commentators (Mihail Ralea, Constantin Schifirneț, Daniel David etc), the critical spirit, to which also he adds a number of complexes such as that our values are not known, connecting "the ghost of recognition" with the "feeling of our oblivion". For the time being, the texts illustrating these complexes have not been canonized or even reached textbooks. Moreover, these complexes can be traced in another dominant of the Romanian spirit, which Eugen Simion talks about the fatality.However, Eugen Simion believes that, derived from the interpretations given to "Mioriţa"ballad, speculated by Mihai Eminescu and other authors, the fatality remains, however, only a literary theme, a metaphor for accepting the inevitable. 


\section{Discussions}

The limitations assumed by an article oblige of course to selections and customizations. Thus, the topic in question was interpreted through the grid of several myths that communist school programs conveyed with the help of the literary texts that were taught during the communist regime. Although the main writers studied between 1980 and 1989 were inventoried, the study could not track the amputations and mystifications of previous periods. On the other hand, between 1980 and 1989, the communist propaganda had acquired a certain subtlety, and so the identity mythology was more insidious. In addition, the mentality of today's mature generation has the configuration acquired through the high school studies from the mentioned period. However, changes, circumventions, reversals could be observed.

The media texts were random chosen, but the identity structures promoted by the pre-1989 school curriculum, as well as some of the postDecember ones, are in an impressive and somewhat stereotypical number, which would deserve further attention, as they could be the sign of communist intellectual equalisation. Too many media materials would smother, however, the present paper, for which the media reverberations of the identity mythology promoted by the school syllabus represent only a secondary objective, a searching key of the identity content.

\section{Conclusions}

Ovidiu Ivancu [11] notes that "the exit from the communism regime was brutal in the sense of a destroyed Romanian identity profile, with amnesia attacks, with sudden and patriotic reminders and evocations of a largely manufactured national history". We can see how the myth of the saviour hero has maintained its coherence, configuring itself variously, according to the communitarian needs, that of the endangered city, although is no longer cultivated so assiduously by the school syllabus, it was retained as reminiscent of the communist propaganda, the relation with the Other was exacerbated, generating fear and rejection, under the sign of the myth of the alien's domination over the native, the religious spirit was revived after 1989, and the Romanians still define themselves as honest, hospitable and hardworking. There is one thing that is obvious: the national identity goes through dramatic reconfigurations, because communist mythology struggles to resist in the collective mind, while the attempts to demystify it do not find an identity project that could take its place. Add the complexes that are 
sublimated either in a Romanian exceptionalism or in the rhetoric of the small, insignificant literature.

\section{References}

[1] Bator E. Clasa politică din Rădăuți, coruptă şi lipsită de credibilitate, 2016.04.30. Obiectiv. Available from: https://obiectivderadauti.ro/clasapolitica-din-radauti-corupta-si-lipsita-de-credibilitate.

[2] Boia L. Două secole de mitologie națională. Bucureşti: Humanitas; 1999.

[3] Boia. L. Istorie şi mit în conştiinţa românească. Bucureşti: Editura Humanitas; 2006.

[4] Bucur I. Colonizarea culturală a României. 2012.11.14. Familia ortodoxă. nr. 46. Available from: http://www.familiaortodoxa.ro/wpcontent/uploads//2012/11/cuprins-nr-46.jpg.

[5] Ciolan A. Când aud de cultură... (III). Coca-Colonizarea. 2010.10.07. ZF.ro. Available from: https://www.zf.ro/ziarul-de-duminica/cand-aud-de-culturaiii-coca-colonizarea-de-alexandru-ciolan-7454910.

[6] David D. Psihologiapoporuluiroman. Bucureşti:Polirom; 2015.

[7] Jusdanis G. Belated Modernity and Aesthetic Culture. Minneapolis-Oxford. University of Minnesota Press, 1991. In Goldiş A.Alegoria națională în discursul identitar românesc. Available from: https://grants.ulbsibiu.ro/wsa/data/BDI_11_Goldis_TR.pdf, accesed in 1.08.2019.

[8] Gavrilută C. Etnie şi identitate culturală. Available from: http://www.philippide.ro/Romani\%20majoritari_2007/62_GAVRILUTA.p df.

[9] Goldiş A. Alegoria națională în discursul identitar românesc.Available from: https://grants.ulbsibiu.ro/wsa/data/BDI_11_Goldis_TR.pdf.

[10] Ibrăileanu G. Caracterul specific național în literature română.Viața literară. 1922, nr. 11. Available from: https://ro.wikisource.org/wiki/Caracterul_specific_na\%C8\%9Bional_\%C3 $\% \mathrm{AEn}$ literatura_rom $\% \mathrm{C} 3 \% \mathrm{~A} 2 \mathrm{n} \% \mathrm{C} 4 \% 83$.

[11] Ivancu O. Identitate cultural şi mental colectiv românesc în postcomunism. Mituri, imagini, pecepții, repoziționări. Cluj -Napoca:Eikon; 2013.

[12] Lungu A. Preşedintel eluptător. 2014 decembrie 15. DOR. Available from: https://www.dor.ro/dor-18-presedintele-luptator/.

[13] Nicolae A.Un academician se ridică şi cere Academiei Române să oprească Colonizarea României executată pe ascuns prin „grupurile de presiuneSoroş", din instituții şi ministere cheie, 2016.08.27. Available from: https://www.activenews.ro/cultura/Un-academician-se-ridica-si-cereAcademiei-Romane-sa-opreasca-COLONIZAREA-Romaniei-executata-peascuns-prin- $\%$ e $\% 80 \% 9$ egrupurile-de-presiune-Soros-din-institutii-siministere-cheie.-Mesajul-INTEGRAL-136057. 
[14] Marinescu AI. Tipul eroului în cultura română. De la stereotip la comportament politic. Iaşi: Editura Lumen; 2009.

[15] Mărcuț C. Identitate națională în societatea românească de tranziție. Available from: http://web.adatbank.transindex.ro/pdfdok/web1_10_Marcus.pdf.

[16] Negrici E. Iluziile literaturii române.Bucureşti:Cartea românească; 2008.

[17] Popescu CT. Încă o Zi de Sărbătoare Naţională. 2018.07.09. Available from: https:/ / republica.ro/inca-o-zi-de-sarbatoare-nationala.

[18] Ralea M. Fenomenul românesc (1927). Bucureşti: Ed. Albatros; 1997.

[19] Rădulescu-Motru C. Psihologia poporului roman. Bucureşti: Societatea română de cercetări psihologice; 1937.

[20] Rotaru V. Uluitor. Lista bogatilor de la varful judetului. Ei sunt smecheriicare au acumulatavericolosalepespateleoamenilor. 2019.07.02. BZI. Available from: https://www.bzi.ro/uluitor-lista-bogatilor-de-la-varful-judetului-eisunt-smecherii-care-au-acumulat-averi-colosale-pe-spatele-oamenilor-foto699577.

[21] Roxin D. Colonizarea României a început în forță. Iată cum vor fi înlocuiți cei 4 milioane de români plecați peste hotare.... 2018.08.01.Available from: http://www.cunoastelumea.ro/colonizarea-romaniei-a-inceput-in-forta-iatacum-vor-fi-inlocuiti-cei-4-milioane-de-romani-plecati-peste-hotare/.

[22] Ruscior C. Paleologu: Traian Băsescu este un luptător neînfricat, dar trebuie să învețe din greşeli. 2014 decembrie 22. RFI. Available from: https://www.rfi.ro/politic-75843-paleologu-traian-b-sescu-este-un-lupt-torne-nfricat-dar-trebuie-s-nve-e-din-gre-eli..

[23] Schifirneț C. Identitatea românească în contextual identității tendențiale. Revista română de sociologie. 2009; 5-6. Available from: http://arhiva.revistadesociologie.ro/indexe18e.html?option=articles\&lgg=ro \&cntid $=1175$.

[24] Severin A. Colonizarea unei natiuni esuate. 2013.11.08. Available from: http://www.corectnews.com/politics/colonizarea-unei-natiuni-esuate-ii.

[25] Simion E. Identitatea româneasca. 2011.07.07.Cultura. nr. 331. Available from: https://revistacultura.ro/nou/2011/07/identitatea-romaneasca-iv/.

[26] Țomănescu M. Nu vreau occidentalizare dacă înseamnă colonizare. 2016.02.24. Available from: https://www.activenews.ro/cultura/Nu-vreauoccidentalizare-daca-inseamna-colonizare-90135.

[27] Vulcănescu M. Dimensiunea românească a existenței. Bucureşti: Editura Eikon; 2009.

[28] Topală A. Consultanță de 3 milioane de euro la Primăria Capitalei. Puterea. 2012.05.01. Available from: https://www.puterea.ro/eveniment/consultanta_de_3_milioane_de_euro43623.html.

[29] România Liberă. AFP: Luptatorul Traian Basescu si diplomatul Mircea Geoana; 2009, 12 . $03 . \quad$ Available from: 
http://romanialibera.ro/politica/institutii/afp-luptatorul-traian-basescu-sidiplomatul-mircea-geoana-171587.

[30] B1. Henri Gillet: Abia are 40 ani şi "Ioana D'Arc a României" deja provoacă panică în cohorta hoților de tot felul care au jefuit țara. Puțini sunt cei care pot fi sigurică nu vor dormi în puşcărie a douazi. 2015.04.30. Available from: https://www.b1.ro/stiri/eveniment/henri-gillet-abia-are-40-ani-si-ioana-darc-a-romaniei-deja-provoaca-panica-in-cohorta-hotilor-de-tot-felul-care-aujefuit-tara-putini-sunt-cei-care-pot-fi-siguri-ca-nu-vor-dormi-in-puscarie-adoua-zi-109897.html.

[31] Naşul Tv. Televiziunea Libera. Cum a fost praduita imensa avere a sindicatelor comuniste. 2012.09.03. Available from: https://www.nasul.tv/cum-fost-praduita-imensa-avere-sindicatelorcomuniste.

[32] G4 Media.ro. Sondaj INSCOP Research: 35\% dintre români consider corupția drept cea mai mare amenințare, $18,9 \%$ o nouă criză economică, 15 , $4 \%$ un eventual răzoişi $13,9 \%$ scandalurile provocate de clasa politică. 2019.05.20. Available from: https://www.g4media.ro/sondaj-inscopresearch-35-dintre-romani-considera-coruptia-drept-cea-mai-mareamenintare-189-o-noua-criza-economica-15-4-un-eventual-razoi-si-139scandalurile-provocate-de-clasa-politica.html.

[33] Programa şcolară pentru limba şi literature română, clasele IX -XII-a, EDP; 1987.

[34] Programa şcolară pentru limba şi literature română, clasa a X-a, clasa XII-a; 1995.

[35] Programa şcolară pentru limba şi literature română, clasa a X-a, clasa XI-a; 2000.

[36] Programa şcolară pentru limba şi literature română, clasa a IX-a, clasa a X-a clasa XI-a, clasa a XII-a; 2009. 